\title{
21
}

\section{Whānau Ora: An Indigenous policy success story}

\author{
Verna Smith, Charlotte Moore, Jacqueline Cumming \\ and Amohia Boulton
}

\section{A policy success?}

Whānau Ora (which can be translated as 'family wellbeing') ${ }^{1}$ is an innovative approach to Indigenous health and social services policy in Aotearoa New Zealand. The initiative empowers whannau (family) as a whole and devolves to whänau members self-determining processes to improve their cultural, social and economic wellbeing. The initiative's designers aimed for 'the potential of whannau to do for themselves' (Humpage 2017: 480) by minimising their dependence on state-delivered benefits and interventions. Building whänau resilience, and the skills and resources of members to manage their own affairs without interference from others, is critical. Intrinsic to this approach is the concept of a 'strengths' perspective. ${ }^{2}$

\footnotetext{
1 The term 'whannau ora' can be translated in many ways. For the purposes of this research and consistent with usage in the report of the Taskforce on Whannau-Centred Initiatives (2010: 12), it means 'family wellbeing', where 'family' is defined as Māori who share 'familial ties that extend over two or three generations' and have 'collective interests that generate reciprocal ties and aspirations'. 2 Increasingly common also in mainstream service delivery, according to Rapp et al. (2005), strengths-based social work has six hallmarks: it is goal oriented; it requires a systematic assessment of strengths; it sees the environment as rich in resources; it has explicit methods for using these strengths for goal attainment; it is hope-inducing; and the practice of meaningful choice is central and clients have the authority to choose.
} 
The failings of mainstream social services to meet the needs of Māori were outlined in 1988 in the landmark report Puao-te-Ata-tu (Day Break) (Ministerial Advisory Committee on a Māori Perspective for the Department of Social Welfare 1988). In particular, the report stated that mainstream services were monocultural and the impact of institutional racism within government agencies was a significant barrier to Māori wellbeing. However, in spite of numerous efforts on the part of government to improve outcomes for Māori over the following decades, Māori have continued to experience health inequities, lower life expectancy and disproportionate representation within both the care and protection and the criminal justice systems (Boulton et al. 2013). As a result, it became clear to Māori leaders and policymakers that solutions that better reflected Māori aspirations, cultural practices and world views were needed.

Launched in April 2010 following extensive consultation with Māori communities across Aotearoa New Zealand, the Whānau Ora initiative ultimately seeks to address endemic issues of the overrepresentation of Māori whänau in poor social and health outcomes. This is the first time in New Zealand's history such an approach to social service delivery has been funded and implemented nationally, although there have been many localised initiatives resembling Whannau Ora that paved the way. Whānau Ora itself has evolved significantly since its inception and there are a number of grounds on which its success can be demonstrated.

In the first instance, the successful programmatic features of Whānau Ora include: its clear public value proposition that significant outcomes in whänau ora can be achieved 'through eliminating poverty, advocating for social justice and advancing Māori social, cultural, economic and community development in the best interests of the nation' (Māori Party 2008); a plausible underpinning theory of change based on both mainstream and Māori scholarship (Durie 1999; Rapp et al. 2005; Boulton et al. 2013); evidence of considerable progress towards achieving its intended outcomes; and equitably offering access to the program to all New Zealanders. Whānau Ora has achieved early gains for its intended beneficiaries and has succeeded in engaging whannau who were not connected to mainstream social services, or for whom the fragmentation of existing services had led to poor outcomes. Connecting Māori service providers and wrapping support around whänau have helped to overcome this fragmentation, while Whānau Ora 'navigators' have proved successful in building trusting relationships with whänau. 
The designers also achieved success in the process of design (described below). The initiative was designed with high fidelity to Indigenous concepts of whannau ora-appropriately, as whannau were intended to be its primary beneficiaries. To a great extent, it was coproduced with these potential beneficiaries and crafted from extensive consultative dialogue with Māori communities throughout New Zealand in its formative phase. Although it did not attract the funding levels and administrative structures identified as desirable by its designers, a new ministerial portfolio has ensured representation at the highest levels within the executive, increasing funding with each successive year of its operation and, over time, increasing administrative independence from central government controls. Despite criticism by the Controller and Auditor-General at a key point in its development—which referred to unclear purpose, implementation delays and excessive administrative spending-Whānau Ora evolved and has been embedded as a unique policy innovation, improving Māori governance over services for Māori.

In political terms, Whānau Ora should also be seen as a story of strikingly successful policy entrepreneurship, in which a committed politician, Dame Tariana Turia, and her colleagues seized a window of opportunity to devise and implement an approach capable of delivering major socialvalue impacts for Māori whānau. The fact a policy approach explicitly designed around Indigenous concepts, practices and values was established within a political environment that had proved itself to be indifferent to Māori initiatives at best, and outright hostile at worst, is remarkable. The creation of a dedicated ministerial portfolio and budget appropriation signalled to the public that Whānau Ora represented a significant shift away from previous approaches, which often amounted to little more than the cooption of Māori language and concepts into mainstream policies.

With regard to Whānau Ora’s potential for endurance, Patashnik (2008) articulates a framework for assessing whether general interest reforms (by which he means non-incremental change of existing policy) are at risk of unravelling over time. He suggests that factors critical to a reform's survival over time include: the extent to which it has created a new policy network to sustain it; whether it threatens existing competitors in its marketplace; and whether it generates, through policy feedback effects, a new and supportive mindset among preexisting agencies. We argue that Whānau Ora has initiated a new and complementary approach to social development that does not conflict with existing agencies. Patashnik's model of post-reform dynamics envisages a situation in which interest groups 
remain stable, have common policy preferences and make investments based on the expectation that the reform will continue. Whānau Ora has presented an approach for social service agencies to better serve their Màori clients, and we argue that they are showing signs of embracing this approach and incorporating it into their way of working. However, the reactions and coalitional patterns that political actors have towards Whannau Ora do risk the future of this approach. If the new Labour-led Government can embrace this approach to working with Māori whānau, the designers will have created a social development program for Mãori with enhanced levels of decision-making and self-determination, which is their legacy.

In this chapter, the story of the design and implementation of Whānau Ora is told through the words of its designers, implementers and evaluators. A qualitative methodology was adopted, utilising documentary analysis and seeking semistructured interviews with decision-makers, leaders and participants who were directly engaged in the design of Whānau Ora.

In the next section, we present the key concepts embodied in Whānau Ora and the context in which it arose. The policy problem of the continued failure of mainstream social services to meet Māori needs is discussed. In the section 'Design and choice', we describe the development of initiatives to address that problem and show the policy window in which Whānau Ora was created, setting out the resulting timeline of activity and the details of programs and structures established under Whānau Ora. Finally, we analyse the extent to which Whānau Ora can be considered a policy success and present our conclusions.

\section{Contexts, challenges and agents}

Indigenous concepts lie at the centre of the Whānau Ora policy success story. In New Zealand, the terms 'whänau' and 'family' are often used interchangeably in social policy documents. However, this serves to oversimplify what is a far more expansive, fluid and complex social structure while at the same time reinforcing Western cultural assumptions that centre on nuclear family constructions (Lawson-Te Aho 2010). Traditionally, whänau were multigenerational groupings connected by genealogical links traced through both male and female lines. This meant individuals may have links and obligations to more than one whänau (Taiapa 1994). Whänau were a key site for the development of 
Māori identity, a place where the teaching of things Māori occurred and an environment where particular responsibilities and obligations were maintained (Moeke-Pickering 1996). Whänau was also understood as the smallest unit of Māori society, followed by the hapū (subtribe) and iwi (tribe). The interests of individuals or the nuclear family were intimately connected to (and often secondary to) the interests of the wider whanau (Metge 1990). This understanding is critical to unpicking the major departure of whannau-centred approaches from mainstream social service delivery, which is structured around providing services to individuals who may or may not reside within (nuclear) families.

'Ora' is another term used widely within New Zealand's health and social sectors, which is often translated simply as 'wellbeing'. According to Walker (2004: 30), 'the concept of ora means a lot more than wellbeing because it is spiritual, emotional and profound'. In the health sector, ora has been connected with a number of initiatives and the term is often used in compounds such as hauora ('spirit or breath of life'), rapuora ('seeking health'), waiora ('healthy environments') and tipuora ('growing/ developing health') (Durie 1994, cited in Metge 1995: 86). At a broad level, we can therefore summarise the philosophy of whanau ora as the holistic wellbeing of a multigenerational family group. The wellbeing of the individuals within whanau is inextricably linked to the wellbeing of the collective, and vice versa. How this philosophy of whanau ora was transformed into, and implemented as, a social policy approach has created a unique series of challenges and opportunities for policymakers, practitioners and communities.

A number of policy developments have contributed to the evolution of the Whānau Ora approach. These include reforms of New Zealand's health sector, the adoption of whole-of-government approaches to social policy issues and an increasing focus on families and children in policy initiatives. However, while these policy developments arguably created a space in which an integrated approach to social services based on Māori values could evolve, it was a series of political developments that enabled a more comprehensive and innovative Whānau Ora approach to become established.

A significant factor in the evolution of the Whannau Ora approach is the transformation that occurred in New Zealand's public sector in the 1980s and 1990s. As part of a broader political project of structural adjustment (Kelsey 1995), reforms in the health sector saw a shift from a state-run 
bureaucracy to a system of devolved authorities (Boulton et al. 2004). The subsequent separation of the funding and provision aspects of health services in 1993 saw contracting become a central part of the health system, which in turn created a space for Māori organisations that were keen to bid for government contracts. Whereas the state saw the development of Māori health providers as an opportunity for Māori to develop an economic base through partnerships in the health and disability sector (Chant 2013), Māori saw an opportunity for self-determination and an ability to deliver services to their people that were better aligned with their own customs and world views. The number of kaupapa Māori ('by Māori, for Māori') organisations offering services underpinned by tikanga Mãori (Māori values and practices) and Māori models of holistic wellbeing expanded rapidly, from about 25 in 1993 to somewhere in the region of 300 such organisations currently (Boulton et al. 2013; Chant 2013).

The participation of Māori within the health sector was strengthened with further reforms introduced by the Labour-led Government in 2001. The New Zealand Public Health and Disability Act (2000) was particularly important; for the first time, reference to the Treaty of Waitangi was incorporated in such a way as to make provisions for Māori to participate not only in the provision of services, but also in decision-making processes (Boulton et al. 2013). Newly created district health boards were not only required to include Māori representation in proportion to their population (with a minimum of two Māori members), but the Act also compelled them to reduce disparities and improve Māori health outcomes (Boulton et al. 2004). These developments led to a separate Māori health strategy, He Korowai Oranga (lit., 'the cloak of wellness'), which was launched by associate health minister Tariana Turia in 2002. The overall aim of the strategy was for 'whānau ora: Māori families supported to achieve their maximum health and wellbeing' (Ministry of Health 2002: 1). The strategy also acknowledged Māori desire for self-determination:

He Korowai Oranga seeks to support Māori-led initiatives to improve the health of whānau, hapū and iwi. The strategy recognises that the desire of Māori to have control over their future direction is a strong motivation for Māori to seek their own solutions and to manage their own services. (Ministry of Health 2002: 1)

However, although 'whannau ora' was the stated goal of He Korowai Oranga, there was no operational definition of the concept in the document. As Boulton et al. (2004) argue, this was problematic, for while 
Māori may understand the philosophy of whannau ora, this understanding may not be shared by non-Māori or other stakeholders within the health sector. Furthermore, it was also clear that the effectiveness of the strategy was likely to be limited given that many of the variables impacting on Māori health outcomes lay outside the health sector, in areas such as housing, employment and education.

Placing whanau at the centre of social initiatives and social policy is not a new phenomenon, and whannau-centred approaches can be traced back to programs initiated by the Mãori Women's Welfare League in the 1950s and the Tu Tangata programs of the 1970s (Moore 2014). Durie argues that, although the Waitangi Treaty settlement process that emerged during the 1980s and 1990s saw an increasing emphasis on iwi as a focus for Māori development, building capacity at the whänau level was critical in achieving tangible outcomes for Māori:

[A]lthough iwi development will likely continue as an important pathway for Māori advancement, it is also likely that there will be an increasing emphasis on building whānau. Expectations that iwi gains might trickle down to whānau are probably unrealistic, given contemporary Māori affiliations and different priorities between small groups such as whānau and large groups such as iwi. Iwi may well contribute to whānau aspirations but for the most part the tools necessary for building iwi capacities will not be the same tools required for developing whānau capacities, including the capacities for caring, for creating whānau wealth, for whānau planning, for the intergenerational transfer of knowledge and skills within whānau, and for the wise management of whānau estates. (2005: 10)

An evolving focus on whānau within Māori social services also runs parallel with a shift towards policies that focus on families and children and attempts to introduce whole-of-government approaches to complex social issues that have taken shape within the mainstream policy environment over recent decades. One example of this is the Strengthening Families initiative piloted in the mid-1990s in Waitakere City and extended nationally in 1999. The program's aim was to 'deliver core services in the welfare, health and education sectors more effectively to that group of families experiencing the most serious disadvantage' (Department of Social Welfare 2001: 13). 
The opportunity to expand the scope and reach of Whannau Ora beyond the health sector arose with the establishment of the Māori Party and the relationship that formed between it and the New Zealand National Party following the 2008 election. In 1996, changes in New Zealand's electoral system created enhanced opportunities for Māori to wield political influence. The number of dedicated Mãori seats was, for the first time, made proportional to the Māori electoral population, which saw an increase in the number of seats from four to seven by 2002. At the same time, a shift from a first-past-the-post to a mixed-member proportional representation system enabled voters to cast both an electoral and a party vote, which created greater opportunities for smaller parties to enter parliament.

The Māori Party was founded by Tariana Turia and Pita Sharples in 2004, following Turia's resignation from the Labour Party. Turia's resignation was in response to the government's introduction of the Foreshore and Seabed Act (2004), which removed the ability of Māori to test their claims to areas of the foreshore and seabed by vesting ownership in the Crown. Many Māori viewed this move as yet another instance of land confiscation by the Crown and as a betrayal by the Labour Party, which had historically held many of the dedicated Māori seats. By 2008, the Māori Party held five of the seven Māori seats. As a minority government, the National Party's need for support from minor parties saw it enter into a relationship accord and confidence and supply agreement with the Māori Party as part of a National-led government. This enabled key policy concessions for Māori including a review (and eventual replacement) of the foreshore and seabed legislation and a review of New Zealand's constitutional arrangements. However, the most significant policy win was arguably a commitment on the part of National to support the 'whannau first' approach outlined in the Māori Party’s political manifesto.

The manifesto had acknowledged whannau as the unheralded model for achieving economic security, creating social cohesion and stability and strengthening cultural identity' (Māori Party 2004: 21). This reflected the passionate championing of this concept by Turia over the previous decade, initially expressed through He Korowai Oranga (Moore 2014: 51). The accord of 2008 explicitly sought 'significant outcomes in whānau ora' and, once appointed the Minister for the Community and Voluntary Sector under the new government, Turia convened the Taskforce on Whānau- 
Centred Initiatives to develop a policy framework for 'a new method of government interaction with Māori service providers to meet the needs of whānau' (Moore 2014: 53-4).

The taskforce was led by Sir Mason Durie, a prominent Māori academic. It defined whänau as a 'multi-generational collective made up of many households that are supported and strengthened by a wider network of relatives' (Taskforce on Whānau-Centred Initiatives 2010: 13). The concept of Whānau Ora was seen as a philosophy, a model of practice for providers, an outcome goal, a funding mechanism and a foundation for future generations. Fundamental to the Whānau Ora vision set out by the taskforce is that providers should work with whannau instead of only one or two people within a whanau. Also fundamental was the concept of strengths-based rather than deficit-based approaches to whannau needs. Finally, funders, providers and whänau would need to work together and focus on results, not inputs, of service. Taken together, this set of concepts had the potential to drive transformational change in the delivery of government support for whānau.

\section{Design and choice}

There have been two distinct phases in the implementation of Whānau Ora, marked by a change in the structure of delivery. We discuss them here as phase one and phase two.

Phase one consisted of three key initiatives: whänau innovation, integration and engagement (WIIE), which involved funding whänau to make plans to improve their lives and assistance to carry these out; provider capacity-building, to enable groups of providers to establish a combined ability to deliver coordinated and whänau-centred services; and integrated contracting and government support for the initiatives, involving the cooperation of Te Puni Kōkiri (the Ministry of Māori Development), the health and social development ministries and district health boards to develop integrated contracts.

The WIIE Fund was launched to fund whänau to develop their own outcome plans. Up to $\$ 5,000$ was available to develop a plan and up to $\$ 20,000$ to implement it. Whanan had to apply for the funding through a legal entity rather than be funded directly, reflecting perceived concerns about the political and financial risks of directly funding whānau. During 
the four years in which this fund was available, 2,595 whannau were funded to prepare a plan and, of these, 564 were funded to carry out some or all of their plan (OAG 2015: 28).

\section{Box 21.1 Whānau innovation, integration and engagement (WIIE) grants}

In March 2010, the Cabinet agreed that Te Puni Kōkiri would administer the WIIE Fund to invest in a range of activities to build whānau capability, strengthen whānau connections, support the development of whānau leadership and enhance best outcomes for whānau. Below are examples of how the WIIE Fund has been used, drawn from Kōrero Mai e te Whānau ('family stories') (TPK 2013: 20-2).

- A whānau with seven members, the majority of whom are deaf, has had a longterm relationship with a local disability support trust-an NGO service providerand a Māori sign language interpreter who offered them an opportunity to engage with the WIIE Fund. This process has enabled them to progress a whānau vision that began 10 years earlier. Their goal is to be able to bridge the gap and reduce the barriers between the deaf and Māori cultures, and they want to support other whānau turi Māori ('families with hearing disabilities') to do this, too. They provide many goals and solutions that may be useful to increase whānau turi Māori participation in the WIIE Fund, in te ao Māori ('the Māori world') and in society.

- A whānau engaged with the WIIE Fund through an NGO service provider after seeking support to gain custody of their mokopuna ('grandchildren'). The grandparents have a long history of gang affiliation and they openly share their story, identifying activators of change and reflecting on what has supported them to dispel the stereotypes they faced. Their WIIE Fund plan has a primary focus on the safety and wellbeing of their grandchildren, and whānau members have achieved many outcomes so far. In particular, it has been meaningful for them to work through barriers to accessing services as well as actively increasing their engagement in wider society to support their mokopuna. This has included kōhanga reo ('Māori language revival'), Grandparents Raising Grandchildren, the local community board and other services.

- A whānau has been working on a plan for their whenua ('land') to create future opportunities for the whānau as well as to provide benefits to their small, isolated community as a whole. There are 30 participating whānau members and they were able to access the WIIE Fund through their existing whānau trust. The resource has enabled them to actively advance the planning of activities to fulfil their collective moemoeā ('vision') of employment, economic development and utilisation of the whenua. They discuss the whānau outcomes already achieved, including the strengthening of whānau connections to each other and to the whenua. In addition, approximately 200 individuals attended a whānau WIIE Fund event that was open to members of the local community.

The service delivery capability fund was available to collectives of providers who held contracts with district health boards or the ministries of health or social development, and who were willing to enter into a formal, collaborative relationship to deliver services for whannauservices that were both easier for whannau to access and delivered in a whänau-centred way. To complement this work, a team within the Ministry of Social Development designed and implemented an integrated 
contract, subsuming multiple contracts, for 28 providers within the collectives. Initially, services were dispersed through a network of locally based collectives, guided by 10 regional leadership groups comprising community representatives and regional officials of the joint agencies. Collectives were funded to prepare a program of action and some were then funded to carry out these programs. Such plans included the creation and employment of Whānau Ora navigators to work intensively with whänau to prepare whänau plans and access services and to assist providers to improve their delivery practices for whänau.

\section{Box 21.2 Whānau Ora navigators}

Navigators were a new workforce employed to work intensively with whānau and were funded mostly through the WIIE and provider program of action funding. The Controller and Auditor-General found there were three main roles:

- $\quad$ working with whānau to help them get more control over their lives, such as by helping whānau to identify their needs and prepare a whānau plan and helping them use services effectively

- if needed, helping whānau to access services that meet their needs

- helping the provider collective to change their mindset and practices to deliver whānau-centred services, which might include proposing new services.

A case study in the Auditor-General's report exemplifies this:

A navigator worked with a man and his children (and their partners and grandchildren) to get him prosthetic legs and other aids, which involved advocating for him with the hospital, writing support letters, and applying for grants; get funding - from three sources-for vehicle modification, bathroom alterations and house modifications; resolve delays in getting financial help he was entitled to, which resulted in an improved financial situation ... and refer him to the rural nurse for help in managing his diabetes ... the approach the navigator took enabled family relationships to be strengthened in a range of ways, and the family achieved a greater level of self-management. (OAG 2015: 42)

Phase two of implementation saw the focus of activity shift from regionalised management of devolved funding through Te Puni Kōkiri to the development of funding streams more distanced from whänau control and management but also more independent of government processes.

In 2014, funding was devolved to three independent non-governmental commissioning agencies: Te Pou Matakana (North Island), Te Pūtahitanga o Te Waipounamu (South Island) and Pasifika Futures (Pacific peoples). Strategic leadership was provided by the Whannau Ora Partnership Group of six ministers of the Crown and six iwi members nominated by the $i w i$ chairs forum. The commissioning agencies provided funding support 
for building the capability of whannau and acted as 'brokers in matching the needs and aspirations of whānau with initiatives that assist them to increase their capability (TPK 2016: 8).

\section{Delivery, legitimacy and endurance}

Since their inception, the three commissioning agencies have diverged somewhat in their focus and approach to implementing Whānau Ora. In part, this is due to significantly different levels of funding, which is allocated on the basis of population, geography, level of deprivation and income (TPK 2016). As a result of this funding model, Te Pūtahitanga o Te Waipounamu and Pasifika Futures receive substantially less than Te Pou Matakana-appropriate to reduced levels of need. Another key factor in the differences between agencies is that both Te Pou Matakana and Pasifika Futures emerged out of existing service provider contexts. In particular, Te Pou Matakana was able to leverage significant experience and expertise from Māori social services provider Te Whānau o Waipareira, while Pasifika Futures built on Pasifika Medical Association health services. In contrast, Te Pūtahitanga o te Waipounamu was a newly formed organisation representing a partnership between the nine iwi of the South Island. This newness enabled the South Island commissioning agency to move away from traditional approaches to service delivery and towards investment in whänau innovation and enterprise. As one of our interview participants explained:

What has been helpful about our commissioning approach has been that we were very clear from the onset that we are not there to threaten or to replicate contracts that service delivery [providers] have had up until now. So, we are not going to compete for existing services. I know that Te Pou Matakana will try to, they will compete for existing services. So, their approach ... there are advantages and disadvantages. I mean, we don't have a 20-year back history of working together as mainstream service providers. The approach that Te Pou Matakana took is because they had the benefit of establishing an infrastructure and they have a proven track record of large multi-million-dollar social service contracts. (Participant 2)

Given the constraints on funding, it was critical that the agency's investment strategy required recipients to build sustainability plans with the expectation that enterprises would become financially independent. An evaluation of the establishment and early delivery phases of Te Pūtahitanga o te Waipounamu found that where whanan held the 
funding and therefore the balance of power in any partnership, successful capability-building was more likely. The key to building whannau capability was found to be 'a commissioning model which provided a purpose for capability to be built and that whannau led their own capability building in the pursuit of their aspirations' (Savage et al. 2016: 124-5). This was a process of disruptive innovation-unsettling at first and succeeding when strong and strategic leadership was established.

In a case study of the economic impact of one of the agency's phase one initiatives, describing a scheme to support skills development in young Māori to deliver lifetime benefits, the net present value of potential economic benefits was estimated to be $\$ 5.5$ million for an investment of $\$ 780,000$ - or seven times its cost in economic benefits (Dalziel et al. 2017: 3).

With regards to the programmatic outcomes of Whānau Ora, there are a number of key features that have proved successful. These include the flexibility and enhanced responsiveness of the approach in addressing the needs of whānau, as well as the way in which Whānau Ora has enabled connection with services for whänau who have previously been less engaged with mainstream providers.

The policy development process that led to Whānau Ora was intended to resolve concerns that

health and social services often intervene after matters went wrong for the individual rather than restoring full whānau functioning or extending whānau capabilities ... [and] that government contracting practices had led to many Mãori providers competing for contracts which fostered a piecemeal approach and inhibited collaboration and coordination. (OAG 2015: 9)

Whānau Ora has enabled organisations working alongside whānau to be more flexible and responsive in terms of the range of supports they are able to offer:

When Dame Tariana sent the taskforce out, she knew that Māori service providers, when they went into a house, they could have been quitsmoking coaches or health educators, but the whannau wouldn't want to deal with all that until the other needs in their household had been met ... she recognised that unless you deal with whatever is important to the family then you are not going to get the focus on the healthrelated conditions that you require. And similar to Maslow, who says that 
everybody has needs that ... need to be met at particular times ... unless you deal with those essential items to live then you can't self-actualise. So Whānau Ora is really consistent with that. You deal with whatever is immediate then we can focus on your potential. (Participant 1)

Participants in this research were clear that the flexibility and responsiveness of the approach were key to meeting the needs of Māori for whom mainstream services had failed:

You can look at the majority of social and health policy in this country and it is just there for the transaction ... Care and protection up until the Oranga Tamariki [Ministry for Children] changes [meant] we will just come in and take the child out, they are safe, job is done. Whānau Ora would say we have to follow where the tamaiti [child] or tamariki [young] go; we have to stay here with mum and dad because how do we make sure [that] at some stage they are strengthened [and] they are safe for that child to return? What [the child protection system] didn't do was do any of that healing. They didn't heal the situation; they just removed the ability to be in an unsafe environment ... Whānau Ora stays and says, 'Come on, what are we going to do?' Follow the tamariki, tamaiti to make sure they stay connected. (Participant 1)

Another participant suggests the approach is about a deeply shared experience:

Relationships. It is almost as blunt as Māori can work with Māori because they know and feel the things that affect them. Māori can work with nonMāori as well but, despite the good hearts and the empathy that nurses, doctors have for the general public in social terms and health terms, they cannot make the connection. Despite their own empathy, love, aroha and all that, they just can't make the connection. (Participant 3)

Another significant indicator of programmatic success is the recognition of the critical role navigators have played in Whānau Ora, as described below:

There are two strands: a focus on what better can we do collectively and what better can we do within that whanau? Navigation was always the key to working better in that whānau. Working in a whānau-centred way was always key to Whānau Ora and 'navigators' was the label that was given to them. That is offputting for some, as it seems to mean pointing in the right direction, but really, effective navigators get under the guts of what is occurring in that whanau and ... work with them to develop their goals and aspirations. (Participant 1) 
Whānau Ora navigators have played a critical role in building trusting relationships with whannau. One participant describes being with the prime minister and the finance minster at meetings with whannau who were beneficiaries of the approach:

On every occasion, tears were shed on the back of what Whānau Ora navigators had done for families ... 'That person saved my life' ... they still talked to her as 'Aunty'. This was hugely compelling for me. (Participant 3)

The navigator role has been recognised in analytical work by the New Zealand Productivity Commission as a key innovation arising from Whānau Ora to support seamless access to social services (New Zealand Productivity Commission 2015). It has also been evaluated and assessed as having a significant positive impact, particularly for whänau with complex needs, at an individual and a collective level, in a survey of 50 case studies of services delivered through Whānau Ora navigators in the South Island in 2016 (Savage et al. 2016).

However, extending the gains made by Whānau Ora to the social sector more broadly has also been challenging, with some social sector policies and priorities at times conflicting with whänau-centred approaches. Despite the investment in developing ways of working differently with whanau, the Auditor-General found in her review of Whānau Ora’s first four years that the Ministry of Social Development and the Ministry of Health had no plans to change to a funding model that would take advantage of this shift in focus and practice (OAG 2015: 53). Also problematic is the focus on children in government social policy, which has been further expanded through the recent government's social investment strategy.

How to capture and measure collective outcomes rather than individual outcomes also presents a number of challenges. The set of outcomes initially designed for the program by Te Puni Kōkiri reflected those presented by the taskforce, but also conveyed a greater emphasis on explicit goals for achievement of individual self-management, health, educational, cultural and economic outcomes as well as whänau cohesion and stewardship of the environment (OAG 2015). However, the AuditorGeneral concluded that the measures and the systems implemented to report on them were confusing for all parties. For instance, the measures of Whānau Ora provider collective performance for 2011-12 on which Te Puni Kōkiri chose to report were infant immunisation and early childhood education. It has taken several years for the building of 
knowledge and experience to result in the program delivering its expected benefits. One participant commented that while the principles and outcomes listed in the taskforce's report formed the basis of their model of implementation, principles such as coherent service delivery were less important than supporting innovation and whänau integrity:

In terms of implementation, our focus has been on the Whānau Ora outcomes as being the model ... If I look back at those principles, they are certainly the reason for being - for why we are doing the things we are doing. So, you know, kaupapa tuku iho ['traditional ideas'], best whänau outcomes, all of those form the rationale for the different work streams that we have. We probably underplay the one on coherent service delivery whereas we overplay the whannau integrity one. So, for our implementation of Whānau Ora, we have put a lot more focus on whänau innovation, the responsibilities and the obligations of whannau to do for themselves, rather than, say, traditional services and providers. (Participant 2)

In an evaluation of Whānau Ora initiatives conducted in 2017, 54 whänau participating in 38 initiatives were interviewed to construct a meaningful framework of outcome indicators and to document whānau perceptions of impacts against these outcomes. Outcomes of whänau cohesion, healthy lifestyle and participation in te ao Mãori ('the Māori world') dominated the social value impacts achieved, with self-management, full participation in society, economic security and environmental stewardship achieving lesser impact (Savage et al. 2016: 11).

Whether Whānau Ora can be judged a success in terms of process is less clear. On the one hand, centring the approach on Indigenous values and practices, coupled with the commitment to community consultation during the design phase, meant that Māori whānau, organisations and communities were enthusiastic about the potential of Whannau Ora. However, it can be argued that the implementation of the approach has been impacted by the lack of a clear communication strategy, the institutional realities of New Zealand's New Public Managementintensive approach to state services delivery and limited resourcing.

The transition from design to delivery was characterised by questions about the nature and definition of Whānau Ora. A participant describes the designers' dilemma when seeking to build support for the Whannau Ora initiative: 
A lot of people who are not Māori fail to understand the concept because of the words. Rather than unpicking it and understanding the phraseology, I think the response is that it is some kind of crazy Māori idea. Do you then turn it around and give it a Pākehā [European] term? And we have thought about that. And, to date, my inclination is no-and the reason is that Pākehā are not as well-endowed to do whānau ora. So, if you did that [gave Whānau Ora a Pākehā name], you would give the impression that they are endowed in a way that they are not. Nevertheless, I think that the language difficulty in this case is a barrier to understanding. (Participant 4)

Another participant noted the difficulties in attempting to implement a program that was still being developed:

Definitely, where we have the ability to implement something new and innovative, we have to give it time to develop the foundation, which includes communication. So, if I take on board some of the big ministries, like [the] Ministry of Social Development, they had good understanding at the top, but you start to dig down lower and they didn't understand. And even back down to the service desk of the Work and Income New Zealand [WINZ] office, they never got the messaging around Whānau Ora. So whānau became empowered but they still had to take the Whānau Ora worker with them because the WINZ worker was being really difficult. You give the system the ability to develop properly the foundations required to implement it, then you communicate what it is broadly across the system so you have that understanding before implementation starts. And then as you go you have to have quality improvement. (Participant 1)

Subtle changes in the processes of decision-making and choice blunted the intent of the taskforce's recommendations to establish a collectiveoriented, strengths-based, whānau-led approach to achieving improved outcomes. Actors in the political coalition supporting the policy were adaptive in the face of this pressure. As one participant commented: 'You learn to adapt. You have to go with what the government determines. If they are going to make those investment decisions, you have to adapt' (Participant 1).

Adaptation has been a defining feature of the implementation of Whānau Ora. Following the release of the taskforce's report in 2010, decisionmakers chose to defer the recommendation to establish a Māori-led independent trust to govern Whānau Ora. Instead, Te Puni Kōkiri was made the lead agency, with the Ministry of Health and the Ministry of Social Development in support ('the joint agencies'). A national-level 
governance group of community representatives and chief executives of the joint agencies was established. This step reflected the desire of Turia, as the Minister for the Community and Voluntary Sector, to retain close personal and departmental oversight of the development of Whānau Ora (OAG 2015: 13). This was wise given the novelty of the initiative and the new partnership established through the relationship accordboth of which created a heightened climate of political risk. However, commentators saw the Whannau Ora funding arrangements that were implemented as 'a discrete and finite series of contracts between the state and some selected providers', creating a context in which the processes of implementation were said to have been coopted into mainstream and bureaucratised frameworks (Moore 2014: 64). The changes made to institutional arrangements in phase two of Whānau Ora were intended to address this risk.

The Whānau Ora philosophy came into immediate conflict with the institutional realities of New Zealand's NPM-intensive approach to state services delivery. The decision to initially manage Whānau Ora through a Crown department, Te Puni Kōkiri, meant conventional funding and accountability structures rather than the innovative arrangements recommended by the taskforce were chosen, driving it towards a framework of state-determined and individualised outputs delivered within an essentially competitive provider sector (Moore 2014: 63). Accountability for funding was expressed in terms of outputs rather than outcomes, and the goal of establishing high-trust, integrated 'single, simple, results-focused contracts' was ultimately delivered only for a very small number of providers.

Tensions around accountability within the program were exacerbated by inconsistent and confusing descriptions of the aims and the expected results of the first set of initiatives. Consequently, difficulties among providers in interpreting expectations of Whānau Ora, and among evaluators establishing its achievements, occurred in the first four years.

Finally, the reach of Whannau Ora has been limited as a result of the levels of funding allocated by government. In the wake of the 2008 GFC, a climate of fiscal rigour and a determination to return to budget surplus while reducing government debt resulted in severe cuts to public expenditure. The decision was made to reduce the proposed $\$ 1$ billion appropriation for Whānau Ora to $\$ 130$ million of repurposed existing funding. According to one participant: 
It would have had ... more substantive resources to start with and it would have been independent. We were still working on whether it would be a trust or whether it would be some form of Crown entity. All of these things were still being worked through and then, all of a sudden, it's within TPK [Te Puni Kōkiri], it has a much smaller budget and it has completely changed character from what it was. (Participant 4)

In the first four years of implementation, much of the reduced funding appropriation for Whānau Ora was diverted to administration. During that time, $\$ 20$ million was utilised to meet the costs of direct services to whänau. More than one-third was utilised for administration (including research and evaluation) (OAG 2015: 5), giving rise to claims that the program had become more 'provider ora than Whānau ora' (Moore 2014: 63). Despite this, the Auditor-General (OAG 2015: 5) found that 'Whānau Ora has been a success for many families who have a plan to improve their lives' and that 'bringing whānau members together to prepare plans seems to have had benefits that are wider than the plans themselves'.

Whānau Ora owes its existence to the changed political situation in New Zealand in 2008, which enabled a relationship accord to be negotiated between the Māori Party and the National Party. Clearly, Whānau Ora represented a political success for both parties, ensuring the survival of the coalition government. Furthermore, having an independent Māori Party in parliament in 2008 was critical in gaining the leverage required to progress what remains a controversial policy. As a participant observes:

Having a political manifesto commitment to a policy is absolutely fundamental. If we hadn't ... put Whānau Ora into not just the 2008 relationship accord, but the 2011 and 2014 relationship accords, if it hadn't been written in black ink in those documents, that would have been a big risk. (Participant 2)

Also crucial to the success of the program have been the drive and commitment of political leaders to champion Whānau Ora. In particular, the role played by Dame Tariana Turia in maintaining her commitment to whannau-centred approaches - first, in her role as associate health minister in the Labour-led Government during the early 2000s, and then through leading the Māori Party into a relationship with the National Party in 2008. Turia conforms to Kingdon's (2010) classic model of the policy entrepreneur enabled to 'sell' their policy during an open window of opportunity, combining her own agency with an opportunity for structural 
change to achieve major and non-incremental policy innovation. This entrepreneurship was identified by several participants as being critical to progressing Whānau Ora:

Tariana herself and later Te Ururoa [Flavell, co-leader of the Mãori Party following the resignation of Pita Sharples]—-they really modelled Whānau Ora by always taking it seriously. You know, they would refer to their mokopuna [grandchildren], or the love of their mokopuna; they would have photos of their beautiful families; there would always be an emphasis on returning home to Whanganui, or Rotorua, and so there was that consistent messaging that meant that this was not just a policy that was meant for Wellington. This was a policy for life. It was about a passionate leader, but also it aligned with their own personal philosophy and approach. (Participant 2)

You can definitely put that down to the leadership of the time and the ability of Dame Tariana to convince her political colleagues that there is a different way of doing things and statistically Māori are not doing better ... so let us try something different ... That kind of leadership she displayed is critical to social change because she could have those conversations: 'Change the economics of my people and we will see better outcomes for communities.' (Participant 1)

However, regardless of this leadership, Whānau Ora is likely to remain vulnerable to challenge in a political climate that is not always receptive to policies that are explicitly shaped around Indigenous needs, practices and values. Policy initiatives that are perceived to be responding to Māori needs or interests are often subject to intense levels of public and political scrutiny (Moore 2014).

\section{Analysis and conclusions}

Although Whānau Ora was developed as a Māori response to Māori needs, the scope of the program was widened from its initial focus on Māori whänau to encompass all New Zealanders in need. Again, this reflected the need to manage political risk in an environment unsympathetic to policies proposing special arrangements to redress disadvantage in Māori communities (Moore 2014). Also challenging was the idea that, through the formation of whannau plans, whänau took a leading role in identifying their own priorities for change, rather than simply being passive recipients of established social services. Leader of the New Zealand First Party, Winston Peters, was a vocal critic of the WIIE Fund, arguing that it used 
taxpayer money to fund 'family reunions' (New Zealand First 2012). As a result of enhanced levels of scrutiny, Whānau Ora has been subject to a number of government-initiated reviews, with yet another review announced at the time of writing. This scrutiny places increased pressure and costs on those involved in the approach to demonstrate its value. As one interview participant involved in the Whānau Ora commissioning process commented:

We have been in a climate of, I guess, resistance or conservatism about whether Whānau Ora works. And we have always known that we have to be vigilant in proving the impact. That's really why I've insisted that every aspect of our work we get evaluated. We commission our own evaluation so that we can have something available once the criticisms come out. (Participant 2)

Given that Whānau Ora was a signature policy for the Māori Party, the party's failure to reach the required threshold to return to parliament following the 2017 general election means the future of Whānau Ora is now in the hands of a coalition government that may not have the same sense of ownership and commitment to the policy. This is particularly the case given the coalition government currently includes New Zealand First, whose leader has been a persistent and vocal critic of Whānau Ora. In 2018, the new Minister for Whānau Ora, Peeni Henare, announced that a review of Whānau Ora had been commissioned. A review had been planned at this stage of the policy implementation process by previous ministers. The new minister said he wished to see that the Whannau Ora service delivery model was accountable and transparent in the achievement of outcomes for whannau but also asked for ideas to see how the program could be expanded and improved. The review panel, chaired by the independent Centre for Social Impact associate Caren Rangi, has been asked to:

- assess the ability of the Whānau Ora commissioning approach to effect sustainable change in the wellbeing and development potential of whānau

- scope the applicability of a whannau-centred approach as a useful exemplar for improving outcomes for whanau across the government, with an emphasis on the social sector

- explore the extent to which the Whānau Ora service delivery model and commissioning approach are accountable and transparent in the achievement of outcomes for whänau (TPK 2018: n.p.). 
The terms of reference reflect preelection statements from the Labour Party about the need for further investment in the approach (New Zealand Labour Party 2017) and indicate that the new government continues to view Whānau Ora as an important inclusion within the social policy mix, not least because their supporters in the Māori electorates demand this of them.

Although underpinned by clear principles, Whānau Ora has arguably been a policy approach that was developed and implemented 'on the go'. The structures, accountabilities and funding arrangements supporting Whānau Ora have evolved since its launch in 2010, and the approach is likely to continue to evolve in line with the new government's priorities and vision. It is also important to understand that, irrespective of whether or not a Whānau Ora policy approach is continued in its current form (or, indeed, in any form) by government, the philosophy of whannau ora and whänau-centred approaches will remain a central aspect of Māori organisations and communities, as it was before the advent of 'Whānau Ora' as the state-led social policy approach. Furthermore, the capacity of Māori organisations to respond to the needs of their communities, which grew in response to the reforms of the public health system in the 1990s, has been further expanded through the investment, commissioning structures and leadership that have resulted from the approach.

\section{References}

Boulton, A., Simonsen, K., Walker, T., Cumming, J. and Cunningham, C. 2004. 'Indigenous participation in the "new" New Zealand health structure.' Journal of Health Services Research \& Policy 9(2): 35-40. doi.org/ $10.1258 / 1355819042349853$.

Boulton, A., Tamehana, J. and Brannelly, T. 2013. 'Whānau-centred health and social service delivery in New Zealand: The challenges to, and opportunities for, innovation.' Mai Journal 2(1): 18-32.

Chant, L. 2013. Hauora Kotahitanga: Māori health experiences as models for co-operative co-existence between indigenous and non-indigenous peoples. Doctor of Philosophy in Community Health thesis, University of Auckland, Auckland.

Dalziel, P., Saunders, C. and Guenther, M. 2017. Measuring the Impact of Whānau Ora Programmes: He Toki ki te Mahi case study. Christchurch: Lincoln University. 
Department of Social Welfare 2001. Welfare to Wellbeing. Wellington: Department of Social Welfare.

Durie, M. 1999. 'Te Pae Mahutonga: A model for Maori health promotion.' Health Promotion Forum of New Zealand Newsletter 49(2-5 December).

Durie, M. 2005. Te Tai Tini transformations 2025. CIGAD Working Paper Series 5/2005. Palmerston North, NZ: Massey University.

Families Commission 2010. Whānau Strategic Framework 2009-2012. Wellington: Families Commission.

Families Commission 2011. Whānau Yesterday, Today, Tomorrow. Wellington: Families Commission.

Families Commission 2013. What Works with Mãori: What the people said. Wellington: Families Commission.

Humpage, L. 2017. 'Does having an indigenous political party in government make a difference to social policy? The Māori Party in New Zealand.' Journal of Social Policy 46(3): 475-94. doi.org/10.1017/s0047279417000022.

Kelsey, J. 1995. The New Zealand Experiment: A world model for structural adjustment? Auckland: Auckland University Press with Bridget Williams Books. doi.org/10.7810/9781869401306.

Kingdon, J. W. 2010. Agendas, Alternatives, and Public Policies. 2nd edn. London: Longmans.

Lawson-Te Aho, K. 2010. Definitions of Whànau: A review of selected literature. Wellington: Families Commission.

Māori Party 2004. Tiriti o Waitangi. Policy statement. Rotorua: Māori Party. Accessed from: d3n8a8pro7vhmx.cloudfront.net/maoriparty/pages/39/ attachments/original/1455484702/Māori-Party-Policy-2004.pdf? 1455484702 (site discontinued).

Māori Party 2008. Relationship and Confidence and Supply Agreement between the National Party and the Maori Party. 16 November. Rotorua: Māori Party. Available from: d3n8a8pro7vhmx.cloudfront.net/maoriparty/pages/ 47/attachments/original/1443172230/Maori-Party-Confidence-SupplyAgreement-2008.pdf?1443172230.

Metge, J. 1990. 'Te rito o te harakeke: Conceptions of the whaanau.' Journal of the Polynesian Society 99(1): 55-92.

Metge, J. 1995. New Growth from Old: The whanau in the modern world. Wellington: Victoria University Press. 


\section{SUCCESSFUL PUBLIC POLICY}

Ministerial Advisory Committee on a Māori Perspective for the Department of Social Welfare 1988. Püao-te-ata-tū: The report of the Ministerial Advisory Committee on a Máori Perspective for the Department of Social Welfare. Wellington: Department of Social Welfare.

Ministry of Health 2002. He Korowai Oranga: Mãori health strategy. Wellington: Ministry of Health.

Moeke-Pickering, T. 1996. Māori Identity Within Whānau: A review of literature. Hamilton, NZ: University of Waikato.

Moore, C. 2014. A whakapapa of Whānau Ora. Master of Arts thesis, University of Auckland, Auckland.

New Zealand First Party 2012. Peters questions Whānau Ora funding. Press release, 7 February. Available from: www.scoop.co.nz/stories/PA1202/S00059/ peters-questions-whanau-ora-funding.htm.

New Zealand Labour Party 2017. Labour pledges more for Whānau Ora. Press release, 11 September. Available from: www.scoop.co.nz/stories/PO1709/ S00171/labour-pledges-more-for-whanau-ora.htm.

New Zealand Parliament 2010. New Zealand Parliamentary Debates (17 February) 660, 34 .

New Zealand Productivity Commission 2015. More Effective Social Services. Wellington: New Zealand Productivity Commission.

Office of the Auditor-General (OAG) 2015. Whänau Ora: The first four years. Wellington: OAG.

Patashnik, E. 2008. Reforms at Risk. Princeton, NJ: Princeton University Press.

Rapp, C. A., Saleebey, D. and Sullivan, W. P. 2005. 'The future of strengths-based social work.' Advances in Social Work: Special Issue on the Futures of Social Work 6(1):79-90.

Rochford, T. 2004. 'Whare Tapa Wha: A Māori model of a unified theory of health.' Journal of Primary Prevention 25(1): 41-57. doi.org/10.1023/B:JOPP. 0000039938.39574.9e.

Savage, C., Leonard, J., Grootveld, C., Edwards, S. and Dallas-Katoa, W. 2016. The Evaluation of Wave One Initiatives: Te Putahitanga o te Waipounamu. Wellington: Ihi Consultancy.

Smith, V. 2018. Bargaining Power: Health policymaking in England and New Zealand. Singapore: Palgrave Macmillan. doi.org/10.1007/978-981-107602-2_7. 
Taiapa, J. 1994. The Economics of the Whänau: The Mãori component-Tã Te Whānau Ohangā. Palmerston North, NZ: Department of Māori Studies, Massey University.

Taskforce on Whānau-Centred Initiatives 2010. Report of the Taskforce on Whanau-Centred Initiatives. Wellington: Office for the Community and Voluntary Sector.

Te Puni Kōkiri (TPK) 2009. Pānui Whāinga 2009-2012: Statement of intent 2009-2012. Wellington: TPK.

Te Puni Kōkiri (TPK) 2013. Kōrero Mai e te Whānau: Whānau stories of integration, innovation and engagement. Wellington: TPK.

Te Puni Kōkiri (TPK) 2016. Formative Evaluation of the Whānau Ora Commissioning Agency Model. Wellington: TPK.

Te Puni Kōkiri (TPK) 2018. Whānau Ora Review. Wellington: TPK. Accessed from: www.tpk.govt.nz/en/whakamahia/whānau-ora/whānau-ora-review (site discontinued).

Walker, R. 2004. Ka Whawhai Tonu Matou: Struggle without end. 2nd edn. Auckland: Penguin. 
This text is taken from Successful Public Policy: Lessons from Australia and New Zealand, edited by Joannah Luetjens, Michael Mintrom and Paul 't Hart, published 2019 by ANU Press, The Australian National University, Canberra, Australia.

doi.org/10.22459/SPP.2019.21 